Copyright (C) 2021 by Cherkas Global University

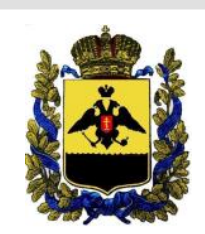

Published in the USA

Bylye Gody

Has been issued since 2006.

E-ISSN: $2310-0028$

2021. 16(4): 1661-1670

DOI: $10.13187 /$ bg.2021.4.1661

Journal homepage:

https://bg.cherkasgu.press

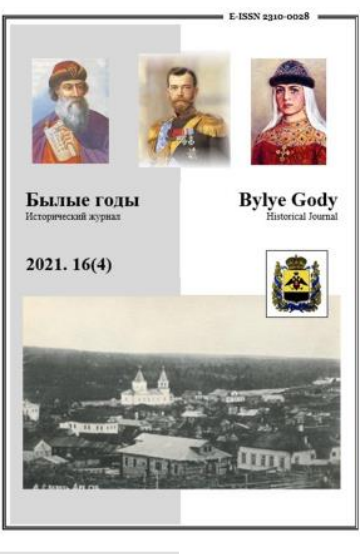

\title{
Political and Public Activity of the Institute of Batyrs of Western Siberia as Part of the Russian Empire (XVIII-XIX centuries)
}

\author{
Yerke T. Kartabayeva a , *, Gulzhan S. Bedelova a, Aitolkyn A. Toktagan b, Nurgul N. Akpanbet c \\ a Al-Farabi Kazakh National University, Almaty, Kazakhstan \\ b Kazakh National University of Arts, Nur-Sultan, Kazakhstan, Kazakhstan \\ ${ }^{c}$ L.N. Gumilyov Eurasian National University, Nur-Sultan, Kazakhstan
}

\begin{abstract}
The proposed scientific article, based on the data of Kazakh and Russian archives, examines the political and social activities of the institute of batyrs who served in Western Siberia as part of the Russian Empire in the XVIII-XIX centuries. After joining the Russian Empire, there were a number of changes in the structure and direction of development of the institute of batyrs of Kazakh society. First of all, it is necessary to pay attention to increasing the political and diplomatic missions of the batyrs. The tsarist government intensified the political activity of the Kazakh batyrs of the West Siberian Steppe, involving them in various state and border issues. It must be recognized that at the previous stage, the activities of the Batyr Institute were limited exclusively to military purposes. In the XVIII-XIX centuries, Russian researchers who were in the Kazakh steppe for various reasons characterized the comprehensive development of the role of batyrs in society. During the analysis of the Russian archival data, we were convinced that the position of the Batyr institute in the system of power has changed. They successfully carried out a connecting activity between the common people and the ruling khan-sultans. Representatives of the Batyr Institute were able to effectively interact with the tsarist administration to resolve conflicts that occurred in the districts of the fortress lines. Also, state initiatives to resolve intertribal conflicts in Kazakh society and their elimination were significantly influenced by the authority of the batyrs in the public environment. Such batyrs as Bogenbai, Kabanbai, became advisers to the khan-sultans. One of the changes that took place in the institute of batyrs during this period can be called their ascent to the rank of the ruling elite of society. Having gained the trust of the tsarist government, the batyrs achieved the position of foreman, tarkhan.
\end{abstract}

Keywords: batyrs, Russian Empire, Kazakh society, Western Siberia, Institute of batyrs.

\section{1. Введение}

В конце XVIII века роль института батыров по политико-общественным вопросам в казахском обществе Западной Сибири существенно изменилась что в первую очередь тесно связано с вхождением казахского общества в состав Российской империи. В этот период проявилась самостоятельность института батыров в системе власти и наблюдалось явление отделения от ранее сложившихся рамок. Для более глубокого понимания сути исследования необходимо дать оценку содержанию понятия «батыр». Батыр - это звание, которое присваивалось воинам, вступавшим в бой и побеждавшим своих соперников. С нашей точки зрения, деятельность батыров в кочевом обществе до конца XVIII века характеризуется двумя действиями: 1) совершать грабительские набеги на караванные дороги или другие регионы и тем самым обеспечивать социальные потребности своего рода; 2) осуществлять предводительство над степными отрядами в борьбе с внешним врагом.

\footnotetext{
${ }^{*}$ Corresponding author

E-mail addresses: madina.imanbaeva@mail.ru (Y.T. Kartabayeva), gg_researcher@yahoo.com (A.A. Toktagan)
} 
В дальнейшем в связи с изменением общественно-политических условий деятельность и роль батыров в обществе претерпели изменения. Если в XV-XVIII веках для политической власти батыры были инструментом грабительских и военных целей, то в конце XVIII века изменилась направленность их деятельности.

Царское правительство поддержало представителей института батыров, чтобы снизить влияние абсолютного правления ханов и султанов в обществе. Это изменение привело батыров к их вмешательству в политико-дипломатические отношения.

\section{2. Материалы и методы}

Исходя из направления исследования и характера материалов, источники можно разделить на три группы: архивные материалы, сборники опубликованных документов и источники личного происхождения.

1. Архивные материалы. Основная часть архивных материалов, относящихся к теме, представлена Центральным государственным архивом Республики Казахстан (Алматы, Казахстан), Государственным историческим архивом Омской области (Омск, Российская Федерация), а также Государственным архивом Оренбургской области (Оренбург, Российская Федерация). В них в основном хранится ведомственная переписка между Оренбургской пограничной комиссией и правителями казахских племен, приказы по урегулированию перекочевки казахских аулов XVIIIXIX веков. Документы данных архивов содержат также сведения о деятельности казахских батыров в пограничных зонах.

2. Сборники опубликованных документов представлены двумя работами: «Из истории казахско-российских отношений. XVIII век. Сборник документов» (Из истории, 2019) и «Из истории Великой степи (последняя четверть XVIII в.). Сборник документов» (Из истории, 2020).

3. Источники личного происхождения. К ним относятся воспоминания и дневники чиновников и путешественников. Среди них можно назвать труды А.К. Гейнса «Киргизские очерки» (Гейнс, 1866), Б. Залесского «Путешествие в казахские степи» (Залесский, 1991), И.И. Крафта «Из киргизской старины» (Крафт, 1900), а также записки Е.К. Майендорфа «Путешествие из Оренбурга в Бухару» (Мейендорф, 1975).

Рассмотрим эти работы по отдельности. В материалах, собранных экспедицией А.К. Гейнса, занимавшейся изучением быта казахского общества на территории Западно-Сибирского генералгубернаторства второй половины XIX века, собраны актуальные данные о деятельности института батыров (Гейнс, 1866). В частности, уделено внимание процессу вмешательства батыров в политическую власть и ее предпосылкам. По мнению А.К. Гейнса, роль батыров в решении политикосоциальных проблем в обществе является значительной. Однако наиболее активно они проявили себя в решении межплеменных конфликтов (Гейнс, 1866: 159).

В 1851 г. оренбургский генерал-губернатор и командир Отдельного корпуса В.А. Обручев организовал геологоразведочную экспедицию по территории Уральской, Тургайской областей. Большое значение имеют воспоминания Б. Залесского, участвовавшего в данной экспедиции (Залеский, 1991). Б. Залесский описал, что в казахском обществе батыры были политическими лидерами определенного рода или аула. Одним из них является Есет Котибарулы (Залесский, 1991: 54). Необходимо понимать, что в период экспедиции Б. Залеского изменилась структура и деятельность института батыров.

В исследовании Е.К. Мейендорфа (Мейендорф, 1975), написанном на основе воспоминаний о его путешествии из Оренбурга в Бухару в первой половине XIX века, собраны ценные сведения, касающиеся военного искусства народов Центральной Азии и его представителей, в том числе и о роли батыров в общественно-социальных процессах. С точки зрения Е.К. Мейендорфа, одной из групп, заинтересованных в процветании торговли рабами в Туркестанском крае, являются батыры (Мейендорф, 1975: 42). В его труде проанализирована война между хивинцами и казахами и ее последствия. Кроме того, он обратил внимание на традицию «барымта» (кровная месть), характерную для кочевых обществ Центральной Азии. По мнению автора, активными ее приверженцами являются батыры (Мейендорф, 1975: 38).

В работе мы опирались на историко-типологический метод с целью выявления отличия института батыров от других общественно-административных институтов. Особенно важно было определить отличия от институтов биев и султанов. Кроме того, был использован принцип критического анализа в контексте объективной оценки совокупности взглядов и позиций авторов исследуемых трудов о деятельности института батыров. Причиной тому часто становятся факты того, что батыр, ставший объектом исследования, является потомком или земляком автора. Сложились различные исторические концепции о развитии и значении института батыров в государственном устройстве. Их формированию способствовали историко-идеологические факторы. Особенно это заметно отразилось в советской и современной науке, в связи с чем широко использовался проблемно-хронологический метод в выявлении нераскрытых сторон данной темы. 


\section{3. Обсуждение}

Историография института батыров в рамках хронологического принципа может быть разделена на три периода: дореволюционный, советский и современный.

В историографии дореволюционного периода роль батыров была подробно проанализирована применительно к области военной истории. Известный русский исследователь А.И. Левшин, изучая ход казахско-джунгарских войн, дал оценку признанным в них отдельным батырам (Левшин, 1996). Например, в его исследовании были названы имена казахских батыров Богенбая, Кабанбая, Жанибека и др. (Левшин, 1996: 75).

В историографии советского периода образ батыров описан однозначно. По принципам идеологии тех лет батыры признавались одной из главных движущих сил обострения классовой борьбы: историки характеризовали деятельность института батыров как силу, противоположную абсолютной власти ханов и султанов. В трудах исследователей (Вяткин, 1947; Апполова, 1948; Ибрагимов, 1961) ханов и султанов изображали как эксплуататоров общества, батыров как сторонников противоположного класса.

По словам историка М.П. Вяткина, батыром является человек, хорошо владеющий военным искусством, обладающий интеллектом, благородством, мужеством. Звание батыра не предполагало преемственности, каждый человек обладал им благодаря личному подвигу. М.П. Вяткин в своем исследовании объясняет, что «широкое распространение титула батыров - одна из отличительных черт кочевого общества» (Вяткин, 1947: 110). Историк Е. Бекмаханов отмечал, что на становление батыров как социальной, политической силы повлияли явления несправедливости и неравенства в обществе (Бекмаханов, 1947: 62-64).

С точки зрения Н.Г. Апполовой, большую роль играли батыры в сохранении стабильности кочевого общества. Они служили механизмом, поддерживающим баланс между политической властью и простым обществом (Апполова, 1948: 95).

С.К. Ибрагимов провел сравнительный анализ деятельности института батыров в Средневековье и в Новое время. В новые времена сближение батыров с угнетенным классом способствовало развитию общества (Ибрагимов, 1961: 176).

В современной историографии всесторонне рассматриваются военно-политические и культурно-социальные аспекты деятельности данного института. В ряде из работ встречаются факты приукрашивания образа отдельного батыра.

По мнению Т.К. Алланиязова, в начале XIX века в обществе начал формироваться процесс восприятия батыров как личностей, признанных в решении актуальных политико-социальных проблем. Например, будущий батыр может быть заметен в мирном урегулировании земельно-водных конфликтов между племенами (Алланиязов, 1997: 12-20). Новые данные о политико-исторической деятельности казахских батыров в период Российской империи можно найти в работе И.В. Ерофеевой (Ерофеева, 2001: 39-43), объектом ее исследования была в основном история казахских ханов Младшего жуза. Одним из ученых, обращавших внимание на деятельность института батыров как на самостоятельную политико-социальную систему, является А.К. Кушкумбаев. С его точки зрения, военные конфликты в Центральной Азии несколько затихли в связи с вхождением казахского общества в состав Российской империи. Эти факторы способствовали изменению функции батыров в обществе: спрос на их военную службу начал снижаться (Кушкумбаев, 2001: 15). Ценным является и труд А. Сейдимбека (Сейдимбек, 2002), стремящегося через изучение устного народного творчества дать научное объяснение образам батыров. В его работе дана разносторонная оценка творчества Дины Нурпеисовой, воспевшей батыров.

Большое значение имеет труд Т.И. Султанова в обобщении нарративных и письменных первоисточников о батырах и их классификации по характерам (Султанов, 2001). Г. Кайргалиева изучала процессы изменения структуры и деятельности института батыров в начале XIX века (Кайргалиева, 2009).

\section{4. Результаты}

Благодаря новым архивным документам, вернулись многие забытые имена, оставившие свой след в истории казахов Западной Сибири на рубеже XVIII-XIX веков. Например, в результате исторических исследований были восстановлены имена батыров Агатая, Доскары и др. Они сыграли значительную роль в политико-социальных преобразованиях Казахской степи, осуществленных после присоединения к Российской империи. Материалы, хранящиеся в архивах и относящиеся к казахским батырам, в основном иллюстрируют их деятельность в степной и пограничной зонах Западной Сибири и Оренбурга.

Политические факторы в Казахской степи в это время были тесно связаны с именем султана Абылая и близких к нему батыров. Он стремился сохранить мир казахского общества, опираясь на помощь Российской империи. Особенно успешные результаты принесла его политическая позиция с империей Цинь. Абылай считался казахским правителем, признанным политической властью России (Из истории, 2020: 15). В отношениях с царской администрацией Абылай-султан часто прибегал к использованию батыров в качестве послов. Ведь во время джунгарского нашествия их подвиги по

$$
-1663-
$$


защите народа принесли им популярность в обществе. Возросла роль института батыров в политикосоциальном плане. Раньше они участвовали в военных действиях и набегах, а после джунгарских войн в истории находят отражение даже факты участия батыров в дипломатических миссиях. Пример этого мы видим в 1760-х гг., когда Кабанбай-батыр совершил посольский визит в Китай (Из истории, 2020: 145).

В середине XVIII века в Прииртышье с укреплением военных линий Российской империи участились пограничные конфликты между кочевыми казахами. Нарушение пограничных зон казахами Западно-Сибирского региона часто фиксировалось в архивных документах. По этим вопросам Абылай также часто переписывался с представителями Российской империи в Сибири. Главной его целью было осуществление подчинения казахов пограничным правилам и контроль за недопущением конфликтов с российскими военными гарнизонами. Например, 15 июня 1748 года Абылай пишет письмо начальнику Иртышского военного рубежа Я. Павлуцкому о возвращении семьи и людей знаменитого батыра рода атыгай Алимбета: «Нашей Всемилостивейшей Государыни Самодержицы милости Ея ожидаем. И для того г-дину полковнику Якову Степановичу Средней Орды Аблай-салтан поклон пишу. И притом прошу: сорок восемь человек взяты в плен, и из оных одинатцать умерли, дватцать четыре голов скота отогнаты, из тринатцати юрт живот увезли, тысяча двести лошадей угнато; обратно отдано четыреста, а достальныя все у вас. Мы люди все всемилостивейшей г-дарыни подданные были, и просим по многим прозьбам наших людей, скот и лошадей отдать. А чего ради не отданы - не знаю» (ЦГА РК. Ф. 11. Кн. 2. Оп. 1. Д. 24. Л. 47).

Абылай совместно с русскими властями проделал большую работу по решению приграничных вопросов. Следует отметить, что царская администрация также придерживалась принципов добрососедских отношений. Причина в том, что на миграционных маршрутах ряда родов наблюдались проявления нарушения пограничных линий. По вопросам контроля за порядком пограничных укреплений султан Абылай поддерживал тесные контакты с представителями царской администрации.

Одним из самых значимых событий XVIII века для казахских батыров стала казахскоджунгарская (калмыцкая) война и возникшие в связи с ней внешнеполитические противоречия. В 50-е годы XVIII века происходил последний этап казахско-джунгарской войны, длившейся полтора века. С одной стороны, в это время Джунгарское государство начало разрушаться из-за борьбы за власть и внутренних раздоров. Әффективно воспользовавшись этим положением, империя Цин вторглась в джунгарские владения и подчинила их себе. В 1756 г., после ликвидации Джунгарского государства империей Цин, ее народ стал переселяться на казахскую землю, которая была в составе Российской империи. Китайцы, преследовавшие джунгарского вождя Амурсану, также перешли на землю Центральной Азии. В это время султан Абылай пытался удержать джунгар не на казахской земле, а на казахско-китайской границе (Ерофеева, 2001: 66).

Казахские батыры во главе с Абылай-султаном сумели вмешаться во внутренние споры джунгарских правителей и использовать их в своих интересах. Одним из документов, свидетельствующих о действиях Абылая в отношении джунгар, является фрагмент устава, направленный царицей Российской империи Елизаветой Петровной И.И. Неплюеву 31 мая 1755 года: «...По рапортам с Иртышской линии от командующих штап-офицеров, объявлено о показании выбежавших из плену киргис-кайсаков зенгорским бухарцеми одной зенгорской женкою, что оные киргисцы пошли на войну в десяти тысячах человеках на Зенгорскую землицу и с ними Аблай-салтан. И от многих-де они слышали, что по раззорении зенгорцов, на новой год, имеют на российския границы нападение учинить. И то-де в крепостях и форпостах, как оная женка показала, людей весьма малое число, и взять тех можно. И, как оной бухаретин, так и женка, пожелали восприять святое крещение» (ГАОО. Ф. 3. ОП. 1. Д. 37. Л. 20-20об.).

Аблай-султан установил стабильные отношения с Российской империей, а также направил в посольство своих надежных партнеров. Российские власти также были намерены поддерживать тесные отношения с казахскими султанами. Соратниками Абылая были в основном батыры, и он привлек их к дипломатической службе. Например, он послал Кулеке-батыра из рода атыгай в русские крепости, расположенные на правом берегу Иртыша. Цель заключалась в том, чтобы добиться от них соглашения о покупке боеприпасов (ЦГА РК. Ф. 11. Кн. 2. Оп. 1. Д. 24. Л. 76).

Такой аргумент можно найти в следующем рапорте премьер-майора Тиряна полковнику фон Лориху от 2 октября 1757 года: «...Присланы от Аблай-салтана, старшина Куляка-батырь, с таким разведыванием: китайское-де войско мирно ль с нами или нет? На что от него, порутчика, объявлено: у нас с китайцами мирно и ссоры никакой не имеетца. И притом он, Куляка, спрашивал же: много ли прошло калмык, и нет ли с ними старшины батыря Амурсаная? На что им объявлено ж: калмык не видали и про Амурсаная не слыхали. А только манием-де чрез проезжавших слышно, якобы оной Амурсана под станцем Белым камнем, при перевозке его чрез реку Иртыш в нер... что он, Амурсана, нечаенно, с другим еще с ним пришедшим азиатом и русским казаком, которой их перевозил, утонули. ... и Аблай-де салтан разстоянием оттоль езды дней с восемь у Белого камня. И при тех разговорах объявлено: от них, киргисцов, от Аблай-салтана» (ГИАОО. Ф. 1. Оп. 1. Д. 58. Л. 82-820б.) 
Большая часть общественно-политической деятельности батыров того времени была напрямую связана с политикой султана Абылая. С признанием Российской империи он стремился к эффективному использованию деятельности института батыров в период правления Средним жузом. Царское правительство также оказало значительную поддержку его действиям. Ряд батыров достигли должности тархана. Один из них - Жанибек-батыр - в 1742 году стал первым среди казахских батыров тарханом (Даланын, 2001: 175). В 1742 г. генерал-губернатор Оренбургской губернии И. Неплюев в письме в Коллегию иностранных дел упоминает Шакшака Жанибека-батыра: «Своим авторитетом и влиянием он превосходит даже ханов и султанов. Казахский народ прислушивается к каждому его слову. Он не из чингизидов, но он очень умный, поэтому он считает себя лучшим» (Даланын, 2001: 176).

Большой удачей можно назвать близость Среднего жуза к России, в том числе к Оренбургу и Орску, что повлияло на сохранность сведений, относящихся к истории казахов в архивохранилищах этих городов. В этот период военно-политический авторитет института батыров достиг небывалого уровня. Их действия ярко проявились в военных противостояниях с Цинь и Джунгарским ханством. Для скорейшей победы над джунгарами и урегулирования политической ситуации в округе представители царства Цин задумали объединить и привлечь на свою сторону казахские военные отряды во главе с Абылаем.

Но Абылай не позволил своим отрядам казахских батыров вступить в союз с Китаем: так как опасался, что Китай, пришедший уничтожить остатки джунгарских войск, разбросанных по казахским степям, подчинит себе казахов и начнет укрепляться. Это же обстоятельство можно наглядно увидеть в рапорте, написанном 5 декабря 1757 г. представителем канцелярии Ямышевской крепости командиру-бригадиру Сибирского корпуса К.Л. Фрауендорфу: «Да между разговорами чрез за толмача татарина Лазырева объявляют, что Аблай-салтан стоит на степи вверх Иртыша реки, где и Кулсара с улусы стоит же. А китайское-де войско ж еще намерено итти на оставшую зенгорского владения одну волость на калмык, кои-де состоят в камню. Да и к Аблаю от китайского войска писано, чтоб и он еще с ним, китайским войском, к походу был готов. Только-де им, киргисцам, еще от Аблая об том приказу нет. А более не объявили и обратно от того форпоста в западную сторону за реку Иртыш отъехали» (ГИАОО. Ф. 1. Оп 1. Д. 6о. Л. 214-215об.).

Из этого рапорта видно, что китайские войска хотели атаковать бежавших джунгар возле казахских отрядов. А чтобы быстрее победить калмыков, китайская армия агитировала казахов присоединиться к ним. Но, исходя из умелой и рациональной системы управления Кульсары батыра и Абылая, ни один казахский батыр не присоединился к китайской армии. Батыры, предвидя возможное нападение со стороны Китая, начинают оборонять свою землю, организуя отряды, которые немедленно идут в контратаку на приближающуюся китайскую армию (Из истории, 2019: 98).

Эту подготовку организовал и возглавил Кульсары-батыр. Когда китайская армия вступала на казахские земли под властью России, Абылай тоже пошел против них со своей армией. Но военные отряды не совершали никаких действий без приказа султана. Об этом говорится в следующем документе - рапорте начальника Семипалатинской крепости полковника И. фон Лориха, написанном 9 декабря 1757 года начальнику Сибирского корпуса К.Л. Фрауендорфу: «По которым разговорам оной старшина ему, поручику фон Фолькману, объявил, что-де ныне ему, старшине, тех аманатов без согласия своей братьи-старшины, и без позволения Аблай-салтана дать не можно. Сверх-де того, по прибытии ево, старшины, в улусы хотел отправить от себя для совету о даче аманатов к протчим старшинам киргис-кайсака. И о том представлять к главному старшине Кулсаре. И пока-де откуда ему ето повеление последует, то он на российскую сторону табунов перегонять не будет. Ибо-де показанному старшине Кулсаре от Аблай-салтана над всем киргиским войском на время команда поручена. А Аблай-де салтан и с ним десять старшин в том-де числе и ево, старшины, брат Сертамбай, и несколько сот выбранных киргис-кайсаков, поехали в китайское войско. Понеже-де оное китайское войско за неимением в степи корму намеренно итти в свою землю, то-де и Аблай-салтан поехал их провожать» (ГИАОО. Ф. 1. Оп. 1. Д. 6о. Л. 329).

Как указано в этом документе, казахские старшины и батыры, переселившиеся на правую сторону Иртыша, указом Абылая не нарушили линии русских военных укреплений. Еще раз подчеркивается, что в кругу Абылая группировавшуюся армию возглавил Кульсары-батыр. Также сообщается о том, что Кульсары-батыр, считавшийся военачальником, не будет гнать стадо на российскую сторону до тех пор, пока не поступит приказ. В свою очередь Абылай-султан разрешил Кульсары-батыру выполнять приказ, порученный от имени всей казахской армии. Описывается отправление султана Абылая в китайскую армию вместе с десятью старшинами, с братом Сертимбаем, а также несколькими сотнями избранных казахов (Из истории, 2019: 61).

Есть информация о том, что китайские войска были вынуждены вернуться на свои земли из-за нехватки продовольствия, а Абылай-султан сам пошел провожать их (Лобысевич, 1872: 52). Отсюда видно, что султан выслеживал и контролировал китайцев своим воинским отрядом, пока не добрался до казахско-китайской границы. Российская администрация также контролировала ход движения казахских войск, в связи с чем они тактически не отдавали приоритет китайским войскам. 
Среди батыров были и люди, умеющие вести переговоры. Сначала они командовали армией, затем вели переписку между султанами, а затем доставляли письма Абылая другим султанам и передавали им информацию, не подлежащую разглашению. Примером тому служит письмо, Кульсары-батыром доставленное сибирскому пограничному начальнику генерал-поручику Ивану Александровичу Деколонгу (ГИАОО. Ф. 1. Оп. 1. Д. 194. Л. 29-320б.). При этом Кульсары-батыр обладал дипломатическими способностями вести переговоры с соседними народами: башкирами, татарами. Отмечается, что он участвовал в ряде переговоров в крае во время пугачевского восстания в 1775 году. Действительно, во время пугачевского восстания между народами региона происходили споры о взаимном объединении или присоединении к пугачевскому восстанию, но присоединения в планах казахской знати не было (ГИАОО. Ф. 1. Оп. 1. Д. 194. Л. 55-58).

Вполне справедливо отметить, что в конце XVIII века общественная деятельность батыров, живших в пограничных зонах казахских степей и русских крепостей, была достаточно высокой. Стоит назвать имена батыров, которые в это время служили в Петропавловской, Усть-Каменогорской крепостях. Особо отличился Кулебакы-батыр, живший в Петропавловской крепости. В 1775 году он попросил у бригадира Петропавловской крепости С.В. Суморокова пастбище. Об этом говорится в письме руководства крепости начальнику Сибирского корпуса генерал-поручику Ивану Александровичу Деколонгу. Сын Кульсары-батыра Кулебак-батыр выступил с предложением расширить пастбища в районе крепости Лебяжье в пограничном районе, где получил одобрение крестьян данного региона (ГИАОО. Ф. 1. Оп. 1. Д. 194. Л. 268-268об.).

Так, в Усть-Каменогорской крепости проживал Мамбет-батыр, общественная деятельность которого была очень активной. В 1775 году командир Усть-Каменогорской крепости комендант А. Самарин направил командиру Сибирского корпуса генерал-лейтенанту И.А. Деколонгу рапорт о том, что через Мамбет- батыра, находившегося в крепости, он отправил письмо Абильфис-султану. Мамбет-батыр поддерживал связь с ташкентскими купцами, что предотвратило споры в сфере торговли (ГИАОО. Ф. 1. Оп. 1. Д. 194. Л. 223-2230б.).

При переезде из Джунгарии в Калмыкию калмыки, оказавшиеся в ауле, занимались воровством в пограничных зонах. Казахские батыры не переставали самостоятельно бороться с ними. Так, Уруссултан написал в письме командиру Сибирского корпуса генерал-лейтенанту И.А. Деколонгу о заслугах Жанузака-батыра, служившего в его подчинении. Опасаясь столкновения с Жанузакбатыром, калмыки отказались перегонять скот (ГИАОО. Ф. 1. Оп. 1. Д. 194. Л. 186-188об.).

В то время отношения между казахами Среднего и Младшего жузов и Россией были хорошими, что было связано с межгосударственной границей. Часть казахов, живших на казахско-русской границе и в районе военных укреплений, построенных российской администрацией, признала власть Российской империи в регионе (Тылахметова, 2020: 52). Процесс присоединения западносибирских казахов к России продолжался медленными, но стабильными темпами. К концу XVIII века местные казахские батыры и старшины стали признавать российскую власть. Все это было сделано для обеспечения единства в регионе под лозунгом, что народы приграничных регионов должны объединяться под одной властью и жить мирно (Abdukadyrov, 2020: 611).

В связи с такими политическими позициями некоторые казахские батыры в последней четверти XVIII века добровольно признали российскую власть в Западной Сибири и Приаралье (Алланиязов, 1999: 84). В их числе были батыры Токтагул Сеитов, Казахбай Дербисалиев, Сугир Кулниязов, Саты Мырзакулов, которые обратились с просьбой о признании царской администрации. Таким образом, признание российской власти получило широкое распространение и среди батыров. Многие из них, хотя и неизвестные всем жузам или всем казахам, были очень известны среди своих соплеменников. У правителей казахских родов, осознавших эффективность присоединения к российской власти, роль батыров оказалась высокой (Кайргалиева, 2009: 74).

В начале XIX века жизнь батыров в казахском обществе постепенно изменилась, однако их институт сохранил свои степные традиции. После того как население части Казахской степи стало подданными Российской империи, произошли изменения во всех областях, чему способствовало уничтожение старого ханства в Среднем и Младшем жузах. Административно-политические реформы, проведенные в 1822-1824 гг., привели к упразднению на казахской земле института ханства в Среднем жузе, а также присоединению султанской власти к местному аппарату колониального управления (Крафт, 1900: 84). Так, в ходе административной реформы казахский Средний жуз был разделен на административные районы, возглавляемые старшими султанами (ага-султанами), а Младший жуз - на три: западный, средний и восточный, возглавляемые султанами (Липец, 1984: 119).

После этой реформы были внесены изменения и в военную систему, когда лица, ранее считавшиеся батырами, но не имевшие на руках ни единой бумаги об окончании учебного заведения, не признавались ни государством, ни обществом. Поэтому для решительных, смелых людей, претендующих на получение государственных званий, возникла необходимость в создании учебного заведения.

Постепенно начало уходить в прошлое понимание того, что можно заслужить внимание и уважение общества с помощью рукопашного боя или побед в военных сражениях или набегах. Так, 
в столице генерал-губернаторства - городе Оренбурге - 2 января 1825 г. было создано Неплюевское военное училище, в котором находилась делегация знатных казахов. На открытие была приглашена делегация во главе с ханом Младшего жуза Шергазы Айшуаковым (Залесский, 1991: 38). Эта школа была в основном военной, она готовила офицеров для армии, но обучающиеся также получали всестороннее образование по гражданским дисциплинам.

Аналогичная военная школа открылась и в городе Омске - центре Западно-Сибирского генерал-губернаторства, где стали принимать детей знати Среднего жуза. В 1826-1845 гг. она была известна как Сибирское линейное казачье училище, а в 1845-1866 гг. - Сибирский кадетский корпус (Басаев, 2003: 23-32). После окончания учебных заведений Омска и Оренбурга выпускники получали всестороннее европейское образование, осваивали язык делопроизводства, изучали письменный русский и арабский, иностранный и восточный языки, а также военные и гражданские специальности (Batyrbekkyzy et al., 2017: 128). Кроме того, выпускники получали воинские звания с правом поступления на военную или гражданскую государственную службу.

По имеющимся данным, Омское военное училище окончили несколько выдающихся казахских деятелей: Чокан Валиханов, его брат Махмут и Гази-Булат Губайдуллин (Алимбаева, 2014: 65). Все они были на государственной службе и имели офицерские звания. Особое место среди них занимает Чокан Чингизович Валиханов, выдающийся путешественник, ученый, внесший значительный вклад в изучение истории, географии и этнографии Центральной Азии и Восточного Туркестана. Также из стен Неплюевской военной школы Оренбурга вышли братья Альмухаммед и Тлеумухаммед Сейдалины, Мухамбет-Салык Бабажанов и другие, ставшие известными личностями в казахской истории и культуре (ЦГА РК. Ф. 25. Кн. 2. Оп. 1. Д. 19. Л. 18). Выйдя из династий казахских ханов и султанов Младшего жуза, они после окончания учебы в Неплюевском кадетском корпусе оставались на государственной службе с дальнейшим карьерным продвижением и внесли значительный вклад в изучение истории и этнографии казахов Младшего жуза (ГИАО. Ф. 19. ОП. 1. Д. 87. Л. 2-2об.).

Общественно-политическая деятельность батыров по-прежнему сохранялась в некоторых областях. Несмотря на то, что они не имели квалификационного документа об окончании специального учебного заведения, их авторитет и влияние в обществе были высоки. Это, конечно, было связано с традицией, хранящейся в народной памяти. А вот деятельность военных специалистов, получивших образование в военных учебных заведениях Российской империи и получивших специальные чины, была иной. Они также служили среди населения и выполняли все работы в рамках закона, став связующим механизмом между российской властью и казахским народом.

\section{5. Заключение}

В результате исследований о батырах Западной Сибири в составе Российской империи появляются новые имена. В ходе нашей исследовательской работы были сделаны новые выводы, касающиеся общественной деятельности ряда батыров. В частности, из забвения были возвращены имена таких батыров, как Шерубай Биболды, Байгозы Наймантайулы. Направления деятельности института батыров претерпели значительные изменения после присоединения к Российской империи. Батыров стали привлекать к делам, решающим политико-социальные проблемы общества, а не только как средство боевой миссии. Администрация Российской империи награждала отличившихся в общественно-полезных делах батыров государственными наградами и представляла им новые направления деятельности. Например, доказательством этому служит присвоение звания хорунжего батыру Ердену Сандыбаевичу в 1856 году.

Изменения в системе деятельности казахского института батыров, как это было отмечено выше, привели к устранению социального неравенства в обществе. Авторитет ханов и султанов, ранее бывших источником авторитарной власти в обществе, ослабел, и институт батыров взял на себя ряд обязанностей административного управления.

\section{Литература}

Алимбаева, 2014 - Алимбаева Б.Б. Роль Оренбургских учебных заведений ХIX века в подготовке казахской интеллигенции / Международная научно-практическая конференция «Народы сопредельных государств России и Казахстана на евразийском пространстве: диалог и сотрудничество». Западно-Казахстанский государственный университет им. М. Утемисова, Уральск, 25 ноября 20142.

Алланиязов, 1997 - Алланиязов T.К. Очерки военного дела кочевников Казахстана. Алматы: Фонд «XXI век», 1997.

Апполова, 1948 - Апполова Н.Г. Присоединение Казахстана к России в 30-х годах XVIII в. АлмаАта: АН ССР, 1948.

Басаев, 2003 - Басаев В.Р. Омский кадетский корпус: история и современность. Омск: Ом. дом печати, 2003. 
Бекмаханов 1947 - Бекмаханов E. К вопросу о социальной природе батыров (XIX век) // Вестник АН КССР. 1947. № 1. С. 62-64.

Вяткин, 1947 - Вяткин М.П. Батыр Сырым. М.: Издательство АН СССР, 1947.

ГАОО - Государственный архив Оренбургской области.

Гейнс, 1866 - Гейнс А.К. Киргизские очерки // Военный сборник. 1866. № 1. С. 145-178.

ГИАО - Государственный исторический архив Омской области.

Даланын, 2001 - Даланын дара ділмарлары. Алматы: ЖШС Қазақстан баспа үйі, 2001.

Ерофеева, 2001 - Ерофеева И.В. Символы казахской государственности (позднее средневековье и новое время). Алматы: Аркаим, 2001.

Залесский, 1991 - Залесский Б. Путешествие в казахские степи. Алматы: Онер, 1991.

Ибрагимов, 1961 - Ибрагимов С.К. К истории Казахстана в XV в. Вопросы филологии и истории стран советского и зарубежного Востока. М., 1961.

Из истории, 2019 - Из истории казахско-российских отношений. XVIII век. Сборник документов / Сост.: Сирик В.А. Алматы: Литера-М, 2019.

Из истории, 2020 - Из истории Великой степи (последняя четверть XVIII в.). Сборник документов / Под. ред. 3.Е. Кабульдинова. Составитель: В.А. Сирик. Алматы: Литера-М, 2020.

Кайргалиева, 2009 - Кайргалиева Г. Исследование Института батыров в казахском обществе // Вестник ЗКГУ. 2018. № 2 (70). С. 220-230.

Крафт, 1900 - Крафт И.И. Из киргизской старины. Оренбург: Тип. Ф.Б. Сачкова, 1900.

Кузембайулы, 2019 - Күзембайулы А. Институт батыров: теоретические и методологические проблемы // Вестник Евразийского гуманитарного института. 2019. № 4. С. 21-27.

Кушкумбаев, 2001 - Кушкумбаев А.К. Военное дело казахов в XVII-XVIII вв. Алматы: ДайкПресс, 2001.

Левшин, 1996 - Левшин А.И. Описание киргиз-казачьих, или киргиз-кайсацких, орд и степей. Алматы: Санат, 1996.

Липец, 1984 - Липец Р. Образы батыра и его коня в тюрко-монгольском эпосе. М.: Наука, 1984.

Лобысевич, 1872 - Лобысевич Ф. Главные начальники Оренбургского края. 1734-1870 // Военный сборник. 1872. № 5. С. 41-68.

Мейендорф, 1975 - Мейендор $\oint$ Е.К. Путешествие из Оренбурга в Бухару. М.: Наука, 1975.

Першиц, 1976 - Першиц А.И. Некоторые особенности классообразования и раннеклассовых отношений у кочевников скотоводов. М.: Наука, 1976.

Сейдимбек, 2002 - Сейдимбек А. Казахское искусство кюя. Астана: Култегин, 2002.

Султанов, 2001 - Султанов Т.И. Поднятые на белой кошме. Потомки Чингиз-хана. Алматы: Дайк-Пресс, 2001.

Тылахметова, 2020 - Тылахметова А.С. Некоторые аспекты внутренней и внешней политики Абылай хана в архивных данных России (1748-1772 гг.) // Электронный научный журнал «еdи.еhistory.kz». 2020. № 3 (23).

ЦГА РК - Центральный государственный архив Республики Казахстан.

Abdukadyrov, 2020 - Abdukadyrov N.M. Ottoman Empire and Russia on the Way to the Independence of Serbia in the 'Eastern Question' // The Journal of Slavic Military Studies. 2020. Vol. 4. Is. 33: 608-620.

Batyrbekkyzy et al., 2017 - Batyrbekkyzy G., Mahanuly T.K., Tastanbekov M.M., Dinasheva L.S. Latinisation of Kazakh alphabet history and prospects // European Journal of Science and Theology. 2017. Vol. 1. Is. 14: 125-134.

\section{References}

Abdukadyrov, 2020 - Abdukadyrov, N.M. (2020). Ottoman Empire and Russia on the Way to the Independence of Serbia in the 'Eastern Question'. The Journal of Slavic Military Studies. 4(33): 608-620.

Alimbayeva, 2014 - Alimbayeva, B.B. (2014). Rol' Orenburgskikh uchebnykh zavedeniy XIX veka v podgotovke kazakhskoy intelligentsii [The role of the Orenburg educational institutions of the 19th century in the training of the Kazakh intelligentsia]. Mezhdunarodnaya nauchno-prakticheskaya konferentsiya «Narody sopredel'nykh gosudarstv Rossii i Kazakhstana na yevraziyskom prostranstve: dialog i sotrudnichestvo». Zapadno-Kazakhstanskiy gosudarstvennyy universitet im. M. Utemisova, Ural'sk, 25 noyabrya. [in Russian]

Allaniyazov, 1997 - Allaniyazov, T.K. (1997). Ocherki voyennogo dela kochevnikov Kazakhstana. [Essays on the military affairs of the nomads of Kazakhstan]. Almaty: Fond «XXI vek». [in Russian] Appolova, 1948 - Appolova, N.G. (1948). Prisoedinenie Kazahstana k Rossii v 30-h godah XVIII v [The accession of Kazakhstan to Russia in the 30 of of the XVIII century]. Alma-Ata: AN SSR.

Basayev, 2003 - Basayev V.R. (2003). Omskiy kadetskiy korpus: istoriya i sovremennost' [Omsk cadet corps: history and modernity]. Omsk: Om. dom pechati. [in Russian]

Batyrbekkyzy et al., 2017 - Batyrbekkyzy, G., Mahanuly, T.K., Tastanbekov, M.M., Dinasheva, L.S. (2017). Latinisation of Kazakh alphabet history and prospects. European Journal of Science and Theology. 1(14): 125-134. 
Bekmakhanov 1947 - Bekmakhanov, E.K. (1947). Voprosu o sotsial'noy prirode batyrov (XIX). [On the question of the social nature of batyrs (XIX)]. Vestnik AN KSSR. 1: 62-64. [in Russian]

CGA RK - Centralny gosudarstvenny arhiv Respubliki Kazahstan [Central State Archive of the Republic of Kazakhstan].

Dalanyn, 2001 - Dalanyn dara dilmarlary. (2001). Almaty: ZHSHS Kazahstan baspa uyi. [Kazakh]

GAOO - Gosudarstvennyy Arkhiv Orenburgskoy oblasti [State Archives of the Orenburg Region].

[in Russian]

Geins, 1866 - Geins, A.K. (1866). Kirgizskie ocherki [Kyrgyz essays]. Voennyj sbornik. 1: 145-178. Region].

GIAOO - Gosudarstvennyy Istoricheskiy Arkhiv Omskoy oblasti [State Historical Archive of the Omsk

Ibragimov, 1961 - Ibragimov, S.K. (1961). K istorii Kazahstana v XV v. Voprosy filologii i istorii stran sovetskogo i zarubezhnogo Vostoka [On the history of Kazakhstan in the XV century. Questions of philology and history of the countries of the Soviet and foreign East]. Moskva. [in Russian]

Iz istorii, 2019 - Iz istorii kazakhsko-rossiyskikh otnosheniy. XVIII vek. Sbornik dokumentov. (2019). Sost.: Sirik V.A. [From the history of Kazakh-Russian relations. XVIII century. Collection of documents]. Almaty: Litera-M. [in Russian]

Iz istorii, 2020 - Iz istorii velikoy stepi (poslednyaya chetvert' XVIII v.) Sbornik dokumentov [From the history of the great stage (the last quarter of the XVIII century.) Collection documents]. (2020). Pod red. Z.Ye. Kabul'dinova. Sostavitel': V.A. Sirik. Almaty: «Litera-M». [in Russian]

Kayrgaliyeva, 2009 - Kayrgaliyeva G. (2018). Issledovanie Instituta batyrov v kazahskom obshchestve [Research of the Institute of Heroes in the Kazakh society]. Vestnik ZKGU. 2(70): 220-230. [in Russian]

Kushkumbayev, 2001 - Kushkumbayev, A.K. (2001). Voyennoye delo kazakhov v XVII-XVIII vv. [Military affairs of the Kazakhs in the XVII-XVIII centuries]. Almaty: Dayk-Press. [in Russian]

Kuzembayuly, 2019 - Kuzembayuly, A. (2018). Institut batyrov: teoreticheskie i metodologicheskie problemy [Institute of Heroes: theoretical and methodological problems]. Vestnik Evraziiskogo gumanitarnogo instituta. 4: 21-27. [in Russian]

Kraft, 1900 - Kraft, I.I. (1900). Iz kirgizskoi stariny [From the Kyrgyz antiquity]. Orenburg: Tip. F.B. Sachkova. [in Russian]

Levshin, 1996 - Levshin, A.I. (1996). Opisaniye kirgiz-kazach'ikh, ili kirgiz-kaysatskikh, ord i stepey [Description of the Kyrgyz-Cossack, or Kyrgyz-Kaisak, hordes and steppes]. Almaty: Sanat. [in Russian] Lipec, 1984 - Lipec, $R$. (1984). Obrazy batyra i ego konya v tyurko-mongol'skom epose [Images of Batyr and his horse in the Turkic-Mongolian exposure]. Moskva: Nauka. [in Russian]

Lobysevich, 1872 - Lobysevich, F. (1872). Glavnye nachal'niki Orenburgskogo kraya 1734-1870

[The chief chiefs of the Orenburg Region 1734-1870]. Voennyj sbornik. 5: 41-68. [in Russian]

Meiendorf, 1975 - Meiendorf, E.K. (1975). Puteshestvie iz Orenburga v Buharu [Travel from Orenburg to Bukhara]. M.: Nauka. [in Russian]

Pershits, 1976 - Pershits, A.I. (1976). Nekotoryye osobennosti klassoobrazovaniya i ranneklassovykh otnosheniy u kochevnikov skotovodov. [Some features of class formation and early class relations among the nomads of pastoralists]. M.: Nauka. [in Russian]

Seidimbek, 2002 - Seidimbek, A. (2002). Kazahskoe iskusstvo kyuya [Kazakh art of kuy]. Astana: Kultegin. [in Russian]

Sultanov, 2001 - Sultanov, T.I. (2001). Podnyatyye na beloy koshme. Potomki Chingiz-khana [Raised on a white felt. Descendants of Genghis Khan]. Almaty: Dayk-Press. [in Russian]

Tylakhmetova, 2020 - Tylakhmetova, A.S. (2020). Nekotorye aspekty vnutrennej i vneshnej politiki Abylaj hana v arhivnyh dannyh Rossii (1748-1772 gg.) [Some aspects of Abylai Khan's domestic and foreign policy in Russian archives]. Elektronnyy nauchnyy zhurnal «edu.e-history.kz. 3(23). [in Russian] Vyatkin, 1947 - Vyatkin, M.P. (1947). Batyr Syrym [Batyr Syrym]. M.: Izdatel'stvo AN SSSR. [in Russian]

Yerofeyeva, 2001 - Yerofeyeva, I.V. (2001). Simvoly kazakhskoy gosudarstvennosti (pozdneye srednevekov'ye i novoye vremya) [Symbols of Kazakh statehood (late Middle Ages and modern times)]. Almaty: Arkaim. [in Russian]

Zalesskii, 1991 - Zalesskii B. (1991). Puteshestvie v kazahskie stepi. Almaty: Oner. [in Russian] 


\section{Политико-общественная деятельность института батыров Западной Сибири в составе Российской империи (XVIII-XIX вв.)}

Ерке Тамабековна Картабаева а, *, Гульжан Сейдуалиевна Беделова а, Айтолкын Айтжанкызы Токтаган ${ }^{\mathrm{b}}$, Нургул Нурланкызы Акпанбет ${ }^{\mathrm{c}}$

а Казахский национальный университет им. аль-Фараби, Алматы, Казахстан

b Казахский национальный университет искусств, Нур-Султан, Казахстан

с Евразийский Национальный Университет им. Л.Н. Гумилева, Нур-Султан, Казахстан

Аннотация. В предлагаемой научной статье, исходя из данных казахстанских и российских архивов, рассматривается политико-общественная деятельность института батыров, служивших в Западной Сибири в составе Российской империи в XVIII-XIX веках. После вхождения в состав Российской империи произошел ряд изменений в структуре и направлении развития института батыров казахского общества. В первую очередь необходимо уделить внимание увеличению их политико-дипломатических миссий. Царская власть активизировала политическую деятельность казахских батыров Западно-Сибирской степи, вовлекая их в различные государственные и пограничные вопросы. Необходимо признать, что на предыдущем этапе деятельность данного института ограничивалась исключительно военными целями. В XVIII-XIX веках российские исследователи, находившиеся в Казахской степи по разным причинам, характеризовали всестороннее развитие роли батыров в обществе. В ходе анализа российских архивных данных мы убедились в том, что положение института батыров в системе власти изменилось: они успешно осуществили связующую деятельность между простым народом и правящими ханами и султанами. Представители института батыров смогли эффективно взаимодействовать с царской администрацией по урегулированию конфликтов, происходивших в окрестностях крепостных линий. Также на государственные инициативы по урегулированию межплеменных конфликтов в казахском обществе и их ликвидации существенно повлиял авторитет батыров в общественной среде. Такие батыры, как Богенбай, Кабанбай, стали советниками ханов и султанов. Одним из изменений, произошедших в институте батыров в этот период, можно назвать их восхождение в разряд правящей элиты общества. Завоевав доверие царского правительства, батыры добились должности тархана.

Ключевые слова: батыры, Российская империя, казахское общество, Западная Сибирь, институт батыров.

\footnotetext{
* Корреспондирующий автор

Адреса электронной почты: madina.imanbaeva@mail.ru (Е.T. Картабаева), gg_researcher@yahoo.com (А.А. Токтаган)
} 